\title{
Effects of cold exposure on feed protein degradation, microbial protein synthesis and transfer of plasma urea to the rumen of sheep
}

\author{
BY P. M. KENNEDY, R. J. CHRISTOPHERSON AND L. P. MILLIGAN \\ Department of Animal Science, The University of Alberta, Edmonton, \\ Alberta T6G 2P5, Canada
}

(Received 13 August 1981-Accepted 23 October 1981)

\begin{abstract}
1. Three diets of barley-canola-seed (Brassica campestris), lucerne (Medicago sativa) or chopped brome-grass (Bromus inermis) were given at intervals of $3 \mathrm{~h}$ to closely-shorn Suffolk wethers held at a temperature of $1-5^{\circ}$ (cold) or $22-24^{\circ}$ (warm). Apparent digestibility of organic matter (OM) and nitrogen was reduced by $0.08-0.05$ and 0.04 units respectively for lucerne and brome-grass diets given to cold-exposed sheep, but no treatment effects on digestibility were observed for the barley-CSM diet. Measurements achieved using infusion of the digesta markers ${ }^{58} \mathrm{Co}$-EDTA and ${ }^{103} \mathrm{Ru}$-phenanthroline $\left({ }^{103} \mathrm{Ru}-\mathrm{P}\right)$ showed that cold exposure depressed apparent OM digestion in the stomach and intestines by 33 and $42 \mathrm{~g} / \mathrm{d}$ for the lucerne diet, and 13 and $35 \mathrm{~g} / \mathrm{d}$ for the brome-grass diet respectively.
\end{abstract}

2. The turnover time $(\mathrm{h})$ of the ${ }^{103} \mathrm{Ru}-\mathrm{P}$ marker in the rumen of warm sheep was 38.9 for barley-CSM, 18.4 for lucerne, and 15.6 for brome-grass. In cold-exposed sheep, ${ }^{103} \mathrm{Ru}-\mathrm{P}$ turnover time $(\mathrm{h})$ tended to be reduced to $32 \cdot 3,12 \cdot 3$ and $15 \cdot 3$ for the three diets, respectively. OM fermentation in the stomach was highly related to ${ }^{103} R u-P$ turnover time for lucerne and brome-grass diets.

3. Cold exposure increased the escape of dietary $\mathrm{N}$ from the abomasum by 0.04 and 0.09 of dietary $\mathrm{N}$ intake for sheep given lucerne and brome-grass diets respectively. Dietary $\mathrm{N}$ degradation was closely related to ${ }^{103} \mathrm{Ru}-\mathrm{P}$ turnover time for lucerne, and to the proportion of large particles in rumen digesta for the brome-grass diet. Estimates of feed $\mathbf{N}$ degradation made by use of information on the rate of fermentation of the diet in nylon bags and ${ }^{103} \mathrm{Ru}-\mathrm{P}$ turnover time were consistently lower than those observed in vivo for barley-CSM and lucerne diets. Intestinal digestibility of non-ammonia $\mathrm{N}$ was not significantly changed by cold exposure.

4. Transfer of urea from plasma to the rumen was $1.42 .5 \mathrm{~g} \mathrm{~N} / \mathrm{d}$ for the barley-CSM and lucerne diets, but the value for brome-grass was $4.5-4.9 \mathrm{~g} \mathrm{~N} / \mathrm{d}$. Cold exposure did not affect urea transfer. The production of ammonia from feed and endogenous protein was approximately 0.66 and $0.47 \mathrm{~g} \mathrm{~N} / \mathrm{g} \mathrm{N}$ intake of barley-CSM and lucerne diets, with no effect of cold exposure. Cold exposure reduced the value from 0.57 to 0.38 for brome-grass.

5. The results are compared with those obtained previously with pelleted hay, and the importance of large particle breakdown in the prediction of $\mathrm{OM}$ and $\mathbf{N}$ fermentation using nylon bags is discussed.

Previous studies on the effects of cold exposure on organic matter (OM) and nitrogen digestion in the rumen and postrumen tract of sheep (Kennedy et al. 1976; Kennedy \& Milligan, 1978) have attributed the depression of OM and $\mathbf{N}$ digestibilities in the gut, observed during cold exposure, to increased reticulo-rumen motility with a consequent reduction in turnover time and digestion of dietary material in the rumen. In addition, more endogenous urea entered the rumen of cold-exposed sheep (Kennedy \& Milligan, 1978). Those studies were restricted to sheep given pelleted brome-grass (Bromus inermis). Young $\&$ Degen (1981) found no difference in total digestibility or rumen turnover time of digesta, between warm and cold-exposed sheep given pelleted barley grain-lucerne meal (Medicago sativa) $(1: 1, \mathrm{w} / \mathrm{w})$, indicating that the magnitude of the depression of rumen fermentation during cold exposure may be dependent on the diet.

The present study provides information on the sites of digestion of three diets selected to provide contrasting patterns of fermentation and of turnover time of rumen digesta. Two of the diets were chopped hay (grass or legume) with the third diet being a concentrate in order to draw conclusions about the effects of cold exposure on digestion of diets other than of pelleted hay. In addition, the rate of transfer of plasma urea to the rumen was measured to derive further information concerning the effect of rumen fermentation rate and ammonia concentration which were suggested by Kennedy \& Milligan (1980a) to have the major controlling influences on clearance of plasma urea into the rumen. 


\section{EXPERIMENTAL}

\section{Animals and management}

Twelve Suffolk wethers, 10-13 months of age and weighing 32-42 kg were used. Each animal was fitted with permanent rumen and abomasal cannulas, and housed in a metabolism cage with continuous lighting at ambient temperatures of $1-5^{\circ}$ (cold) or $22-24^{\circ}$ (warm) during measurements, and during the preceding weeks. Sheep were closely shorn at the beginning and after 2 weeks of each 5 -week period. After 3 and 4 weeks of temperature exposure, ambient temperatures were reduced by $1^{\circ}$ to compensate for wool growth. Intramuscular injections (mg) of retinol 75, cholecalciferol 0.94 and $\alpha$-tocopherol 16 were made at intervals of $14 \mathrm{~d}$.

\section{Diets and feeding}

The two hay diets, brome-grass and lucerne were chopped to a length of 10-50 mm. The concentrate ration comprised $(\mathrm{g} / \mathrm{kg}$ air dry material): rolled barley 924 , canola-seed (Brassica campestris) meal (CSM) 30, ground calcium carbonate 12; calcium hydrogen phosphate 4 , molasses 25 , trace mineralized salt $2 \cdot 5$, vitamin-selenium-ground barley mix 2.5. All diets were given at intervals of $3 \mathrm{~h}$ at a rate estimated (National Academy of Sciences, 1975) to provide an intake of metabolizable energy of approximately $9060 \mathrm{~kJ} / \mathrm{d}$. Water was available $a d$ lib., and cobalt-iodized salt $(10 \mathrm{~g} / \mathrm{d})$ was given with the feed.

\section{Experimental design and schedule}

Each sheep received only one diet for $70 \mathrm{~d}$. Within each diet, two sheep were exposed at each ambient temperature for $35 \mathrm{~d}$, after which they were transferred to the alternative temperature treatment. One sheep given lucerne in the cold did not finish the second experimental period. During each experimental period, the following schedule was followed: days 1-21, adaptation to ambient temperature; days $21-26$, faecal and urine collection, nylon bag experiments, metabolic rate measurements, collection of rumen fluid for in vitro gas production; days 27-33, intraruminal infusion of $\mathrm{Na}_{2}{ }^{35} \mathrm{SO}_{4},{ }^{103} \mathrm{Ru}$-phenanthroline $\left({ }^{103} \mathrm{Ru}-\mathrm{P}\right),{ }^{58} \mathrm{Co}-\mathrm{EDTA}$; days $27-28,\left({ }^{15} \mathrm{NH}_{4}\right)_{2} \mathrm{SO}_{4}$ infusion into rumen, collection of rumen fluid and jugular blood; days 31-33, collection of abomasal and rumen digesta samples; days 33-34, abomasal samples collected for calculation of ${ }^{103} \mathrm{Ru}-\mathrm{P}$ turnover time; days 34-35, infusion of $\left[{ }^{15} \mathrm{~N}\right]$-urea intravenously with collection of rumen fluid and blood samples.

\section{Nylon bag measurements}

The rate of fermentation of each diet was calculated after measurement of the disappearance of $\mathrm{N}$ from $5 \mathrm{~g}$ (ground through a $3 \mathrm{~mm}$ screen) at $6,12,18,24$ or $48 \mathrm{~h}$ of incubation in the rumen. One bag per sheep at each time was used, with sheep considered as replicates. The bags were $90 \times 170 \mathrm{~mm}$, of $53 \mu \mathrm{m}$ porosity $(11$ threads $/ \mathrm{mm}$, thread diameter $39 \mu \mathrm{m})$. On removal from the rumen they were separately washed and squeezed in running water until the wash was colourless.

\section{Metabolic rate and in vitro gas production}

Metabolic rate was calculated from two measurements, each of $0.5 \mathrm{~h}$, of oxygen and carbon dioxide exchange of sheep in a ventilated hood as described by Young et al. (1975). In vitro gas production from two samples per period was measured in triplicate using 1-2 ml portions of anaerobic, strained rumen fluid at $5 \mathrm{~min}$ intervals over $30-60 \mathrm{~min}$ in a differential respirometer (Model GP 20/5, Gilson Medical Electronics Inc., Middleton, Wisconsin, USA). The rate of gas production at the time of sampling was estimated from gas production $v$. period of time after sampling. 


\section{Estimation of abomasal digesta flow and microbial production}

Approximately $10 \mu \mathrm{Ci}$ of ${ }^{103} \mathrm{Ru}$-labelled Tris-(1, 10-phenanthroline)-ruthenium (II) chloride (Tan et al. 1971) and $10 \mu \mathrm{Ci}{ }^{58} \mathrm{Co}-E D T A$, prepared by the method of Uden et al. (1980) but with the addition of ${ }^{58} \mathrm{CoCl}_{2}$, with approximately $60 \mu \mathrm{Ci}$ of $\mathrm{Na}_{2}{ }^{35} \mathrm{SO}_{4}$ in $500 \mathrm{ml}$ water were infused continuously into the rumen for each of $6 \mathrm{~d}$ following a priming dose of infusate $(500 \mathrm{ml})$. Three samples $(100 \mathrm{ml})$ of abomasal digesta were taken at $0.5,1.5$ and $2.5 \mathrm{~h}$ after feeding on three occasions during each of $3 \mathrm{~d}$. Portions of digesta were filtered through Terylene cloth; digesta and filtrate were separately pooled for each sheep.

Once each day, an additional sample $(60 \mathrm{ml})$ of digesta was taken, and a microbial fraction was separated by differential centrifugation (Kennedy et al. 1976). The flow of digesta and microbial protein was estimated after corrections were made for absorption of ${ }^{58}$ Co EDTA from the stomach (Faichney, 1975a), by mathematical recombination of the digesta fractions (Faichney, 1975b). The turnover time of the particulate marker was calculated from the decline with time of ${ }^{103} \mathrm{Ru}-\mathrm{P}$ in six samples of abomasal contents taken during the interval $12-24 \mathrm{~h}$ after cessation of the continuous infusion of markers.

\section{${ }^{15} \mathrm{~N}$ infusions and rumen sampling}

Infusions of $\left({ }^{15} \mathrm{NH}_{4}\right)_{2} \mathrm{SO}_{4}\left(200 \mathrm{mg} / \mathrm{d}, 95 \cdot 3\right.$ atoms ${ }^{15} \mathrm{~N} / 100$ atoms $\left.\mathrm{N}, 0.40 \mathrm{mg} / \mathrm{ml}\right)$ into the rumen or of $\left[{ }^{15} \mathrm{~N}\right]$-urea $\left(100 \mathrm{mg} / \mathrm{d}, 95 \cdot 4\right.$ atoms ${ }^{15} \mathrm{~N} / 100$ atoms $\left.\mathrm{N}, 0.2 \mathrm{mg} / \mathrm{ml}\right)$ into the jugular vein were made for $24 \mathrm{~h}$ following a priming dose $(20 \mathrm{ml})$. Six samples of blood $(10 \mathrm{ml})$ and rumen fluid $(20 \mathrm{ml})$ were taken hourly from 18-24 h, and prepared for the analysis of ${ }^{15} \mathrm{~N}$ and ammonia as previously described (Kennedy \& Milligan, 1978).

Rumen digesta samples $(30 \mathrm{~g})$ were obtained by a sealable sampling tube on six occasions (days 31-33) and subjected to a wet sieving technique (Mudgal et al. 1982) using screens of $2,1,0 \cdot 7$ and $0.25 \mathrm{~mm}$.

\section{Analytical procedures}

Dry matter (DM), OM, cell wall constituents (CWC), organic ${ }^{35} \mathrm{~S}$, and $\mathrm{N}$ concentrations were determined as described previously (Kennedy \& Milligan, 1978).

$\mathrm{N}$ from ammonia and plasma urea was isolated as $\left(\mathrm{NH}_{4}\right)_{2} \mathrm{SO}_{4}$ by the methods of Nolan \& Leng (1972). ${ }^{15} \mathrm{~N}$ was measured using a mass spectrometer (Model 602, VG Micromass Ltd, Winsford, Cheshire, UK). Background abundance of ${ }^{15} \mathrm{~N}$ in samples from each sheep was estimated before infusion of ${ }^{15} \mathrm{~N}$. Urea in plasma was determined by the diacetyl monoxime method of Marsh et al. (1957).

${ }^{58} \mathrm{Co}$ and ${ }^{103} \mathrm{Ru}$ were estimated using a germanium coaxial detector (Model CS10-B316; Aptec Engineering Ltd, Downsview, Ontario) coupled to a multichannel analyzer (series 80, Canberra Industries, Inc., Meriden, Connecticut USA). Standards were prepared from infusates and non-radioactive samples of abomasal digesta. Appropriate corrections for variations in geometry were made.

\section{Calculations and statistical analysis}

Movement of digesta constituents from the abomasum was calculated with reference to the digesta markers $\left({ }^{58} \mathrm{Co}-\mathrm{EDTA}\right.$ and ${ }^{103} \mathrm{Ru}-\mathrm{P}$ ) and the microbial marker (organic ${ }^{35} \mathrm{~S}$ ), as previously described (Kennedy et al. 1976). Dietary $\mathrm{N}$ escaping digestion was calculated by subtraction of endogenous secretions (assumed to be $1.5 \mathrm{~g} \mathrm{~N} / \mathrm{d}$; Phillipson, 1964; Harrop, 1974) and microbial $\mathrm{N}$ from the abomasal flow of non-ammonia N (NAN). Rates of irreversible loss of rumen ammonia and plasma urea, and the entry of plasma urea into the rumen were calculated as described previously (Kennedy \& Milligan, 1978). Production 
of rumen ammonia from feed and endogenous protein was calculated by solution of a two-pool model (Shipley \& Clark, 1972).

The disappearance $(p)$ from nylon bags with time in the rumen was described by an equation of the form $p=a+b\left(1-e^{-c t}\right)$, where $b$ and $c$ were fitted by an iterative least squares procedure (Ørskov \& McDonald, 1979). Degradability $(P)$ estimates were then made using values of the inverse of the turnover time of ${ }^{103} \mathrm{Ru}-\mathrm{P}$ as estimates of fractional outflow rates $(k)$ from the rumen using the equation:

$$
P=a+\frac{b c}{c+k} \quad(Ø r s k o v \& \text { McDonald, 1979). }
$$

Variables were analyzed after fitting one missing value for effects of diet, period, temperature, temperature $\times$ diet and period $\times$ diet interactions, and animal units within diets. Diets were tested against animal units within diets. Period, temperature and interactions were tested against residual (11 df). Animals within units were included in residual. Differences between temperatures within diets were tested for significance by $t$ test.

\section{RESULTS}

Digestion of $O M$ and $C W C$

Exposure of wethers to cold $\left(1-5^{\circ}\right)$ resulted in a substantial increase in heat production of approximately $0.55-0 \cdot 86$, accompanied by a reduction in apparent digestibility of $O M$ for the lucerne and brome-grass diets, compared to wethers maintained at a warm temperature (22-24, Table 1). Cold exposure did not affect OM digestibility for the barley-CSM diet. There was only a trend for lower OM digestion in the stomach of cold-exposed sheep given lucerne and brome-grass, but there was a significant $(P<0.05)$ increase for these sheep in the proportion of digestible OM intake that disappeared in the stomach. This was due to a relatively greater decrease in digestion of $\mathrm{OM}$ in the intestines than in the stomach. The turnover time of ${ }^{103} \mathrm{Ru}-\mathrm{P}$ in the stomach tended to be reduced $(P<0.05)$ by cold exposure of sheep given lucerne, but not for barley-CSM or brome-grass. However there was a positive relationship between OM truly fermented in the stomach $(F ; \mathrm{g} / \mathrm{g}$ OM intake), calculated from apparent $O M$ digestion and microbial $O M$ flow from the stomach, and ${ }^{103} \mathrm{Ru}-\mathrm{P}$ turnover time $(T ; \mathrm{h})$ within both lucerne and brome-grass diets as described by the equations:

$$
\begin{aligned}
\text { lucerne, } F & =0.00887( \pm 0.00240) T+0.423(r 0.86) \\
\text { brome-grass, } F & =0.0113( \pm 0.0047) T+0.367(r 0.70)
\end{aligned}
$$

Inclusion of the proportion of large particles (retained on $1 \mathrm{~mm}$ plus $2 \mathrm{~mm}$ screens; $L$ ) in a multiple regression did not improve the precision of prediction for lucerne, but resulted in a significant $(P<0.05)$ improvement for brome-grass. The latter relationship was:

$$
F=0.00971( \pm 0.00386) T+0.474( \pm 0.023) L+0.113(r 0.85)
$$

Reliable estimates of rumen fluid pool sizes and turnover rates could not be made owing to the variable $(0 \cdot 1-0 \cdot 3)$ apparent adsorption of ${ }^{58} \mathrm{Co}$-EDTA to particulate digesta in the stomach.

\section{$N$ transactions in the gastrointestinal tract}

Apparent $\mathrm{N}$ digestibility in the gastrointestinal tract was significantly $(P<0.05)$ reduced by cold exposure of sheep given lucerne and brome-grass diets but not the barley-CSM diet (Table 2). Because apparent intestinal NAN digestibility ( $\mathrm{g} \mathrm{N} / \mathrm{g} \mathrm{N}$ entering intestines) was not affected by cold exposure, the reduced digestion of $\mathrm{N}$ in the gastrointestinal tract for the hay diets was attributable to an increased flow $(1 \cdot 1-2 \cdot 4 \mathrm{~g} \mathrm{~N} / \mathrm{d})$ of NAN from the abomasum of cold-exposed sheep. Partition of the flow of NAN from the abomasum, using 


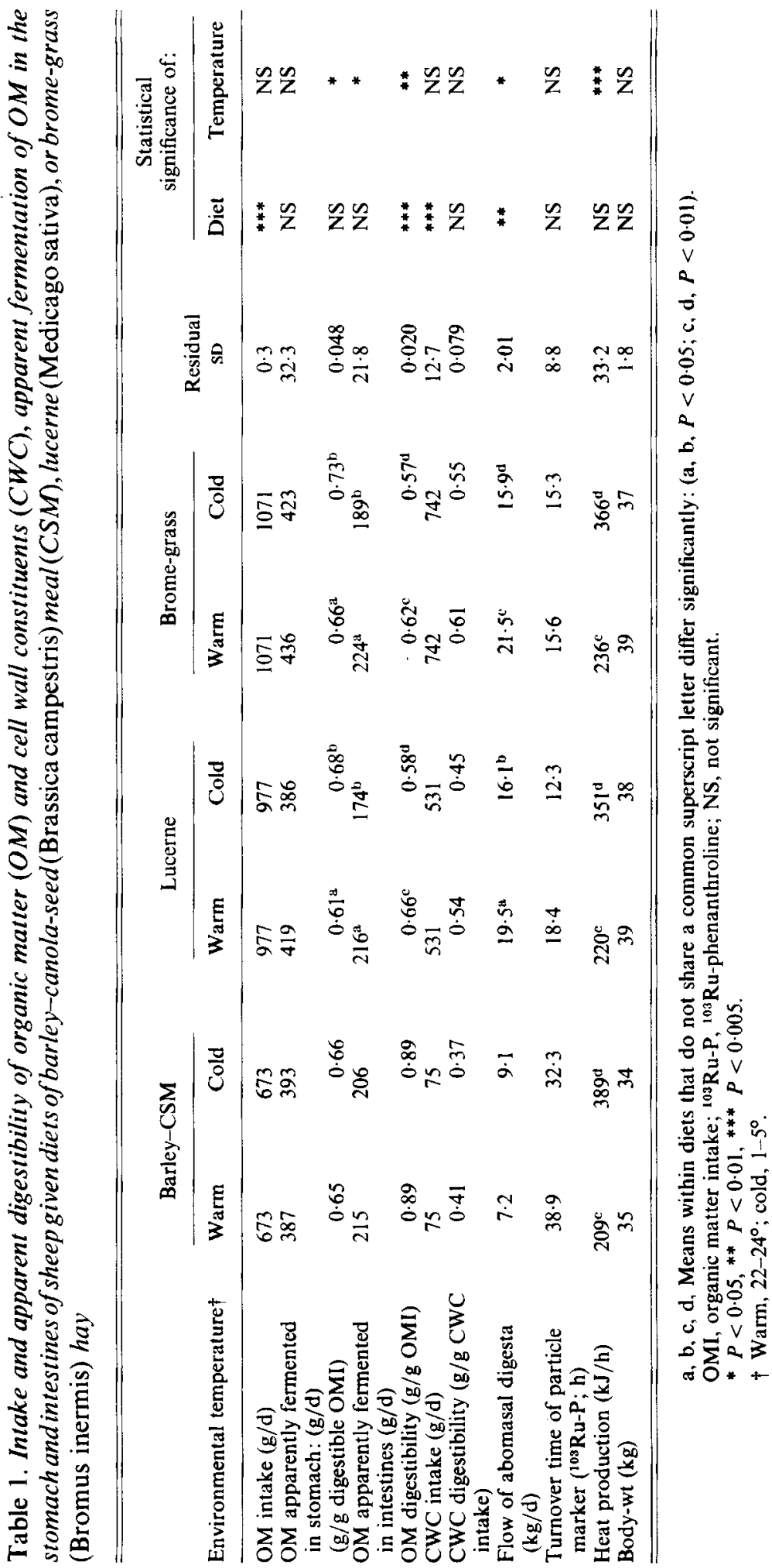


P. M. Kennedy, R. J. Christopherson and L. P. Milligan

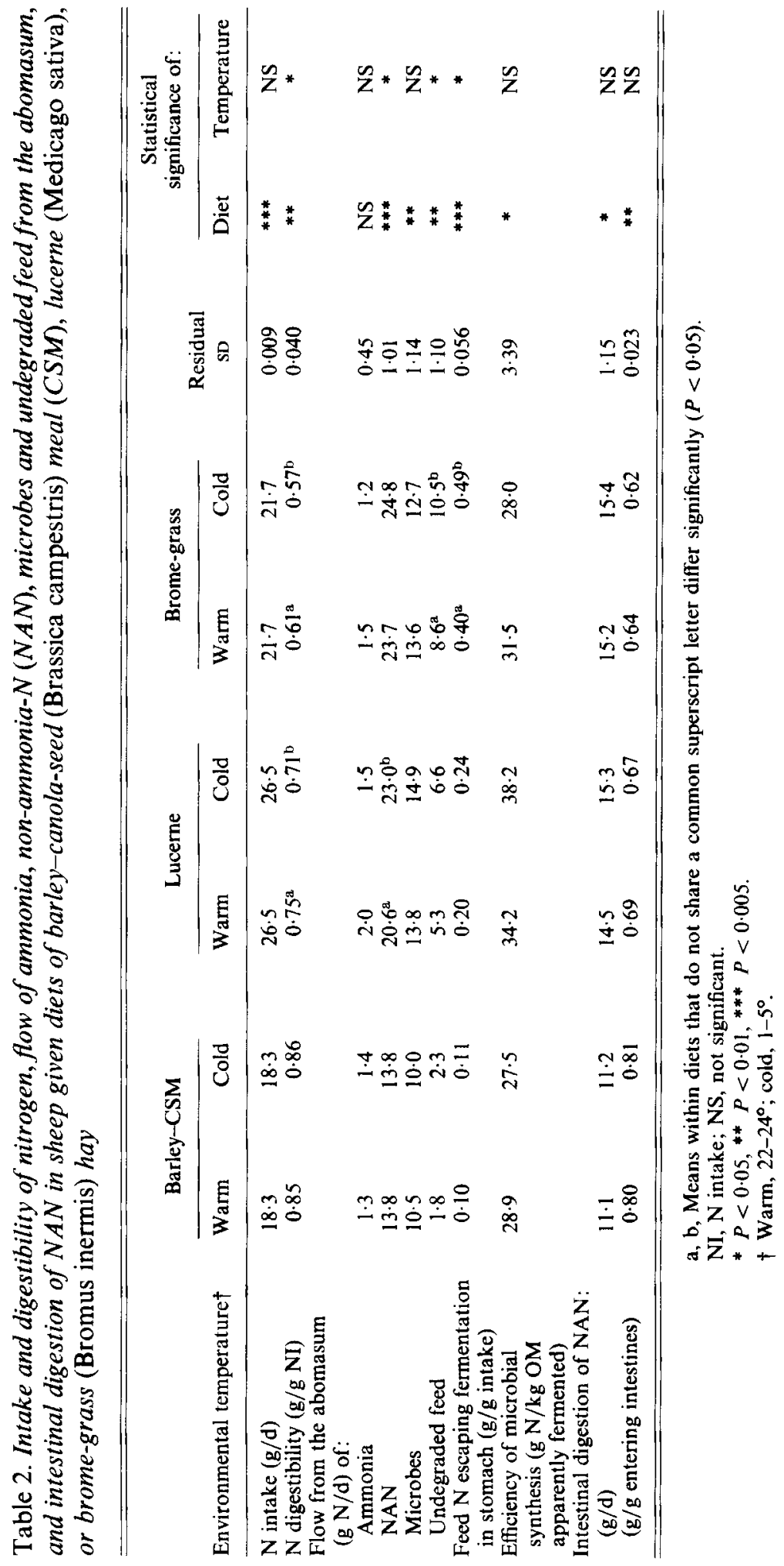




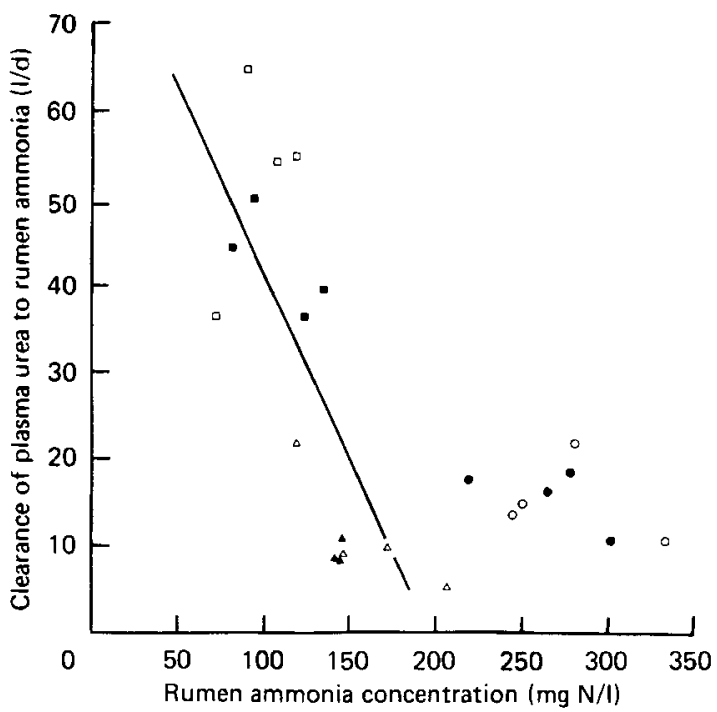

Fig. 1. Relationship of clearance of plasma urea to the rumen with rumen ammonia concentration in sheep given chopped brome-grass (Bromus inermis; $\square, \square$ ), lucerne (Medicago sativa; $\Delta, \Delta$ ) or barley-canola-seed (Brassica campestris) meal diet $(O, \bigcirc)$ at $22-24^{\circ}(\square, \triangle, \bigcirc)$ or $1-5^{\circ}(\square, \Delta, O)$. Brome-grass and lucerne: $y=-0 \cdot 440 x+86 \cdot 1(r, 0 \cdot 76)$.

${ }^{35} \mathrm{~S}$ as a microbial marker and assuming endogenous protein leaving the abomasum amounted to $1.5 \mathrm{~g} \mathrm{~N} / \mathrm{d}$, revealed that the increased flow of NAN was principally undegraded dietary protein (Table 2).

Efficiency of synthesis of microbial protein was highest for sheep given lucerne, but within diets there was little correlation $\left(r^{2} 0.02-0.42\right)$ between the turnover time of ${ }^{103} \mathrm{Ru}-\mathrm{P}$ and efficiency of microbial synthesis.

Tracer-derived estimates of irreversible loss rates of rumen ammonia and plasma urea, and entry of $\mathrm{N}$ into the rumen ammonia pool from plasma urea and from protein fermentation are presented in Table 3. Cold exposure of sheep did not significantly affect irreversible loss of $\mathbf{N}$ from the urea and ammonia pools. However, rumen ammonia production from fermentation of brome-grass and endogenous protein was reduced by cold exposure by $4 \cdot 1 \mathrm{~g} \mathrm{~N} / \mathrm{d}$.

The transfer of urea to the rumen ammonia pool contributed only $0 \cdot 10-0 \cdot 16$ of ammonia flux for the barley-CSM and lucerne diets, but this proportion was $0 \cdot 26-0.36$ for sheep given brome-grass (Table 3 ). This urea input contributed $1.4-4.9 \mathrm{~g} \mathrm{~N} / \mathrm{d}$ to the rumen, representing clearance values (the volume of plasma which would contain an amount of urea equal to the urea transfer) of $9-16 \mathrm{l} / \mathrm{d}$ for the barley-CSM and lucerne diets, and $43-53 \mathrm{l} / \mathrm{d}$ for the brome-grass diet. Cold exposure did not significantly affect urea transfer. The relationship between clearance of plasma urea to the rumen $(C ; 1 / \mathrm{d})$ and rumen ammonia concentration ( $A ; \mathrm{mg} \mathrm{N} / \mathrm{l}$ ) for the hay diets was described by the equation:

$$
C=-0.440( \pm 0 \cdot 104) A+86 \cdot 1(r 0 \cdot 76)
$$

Clearance values for the barley-CSM diet were not described by this relationship (Fig. 1).

\section{Rumen digesta particle size and in vitro fermentation}

The results of sieving of rumen digesta showed that approximately 0.6 of hay particles in the rumen were retained on the 1 and $2 \mathrm{~mm}$ screens, compared to 0.4 of barley-CSM 


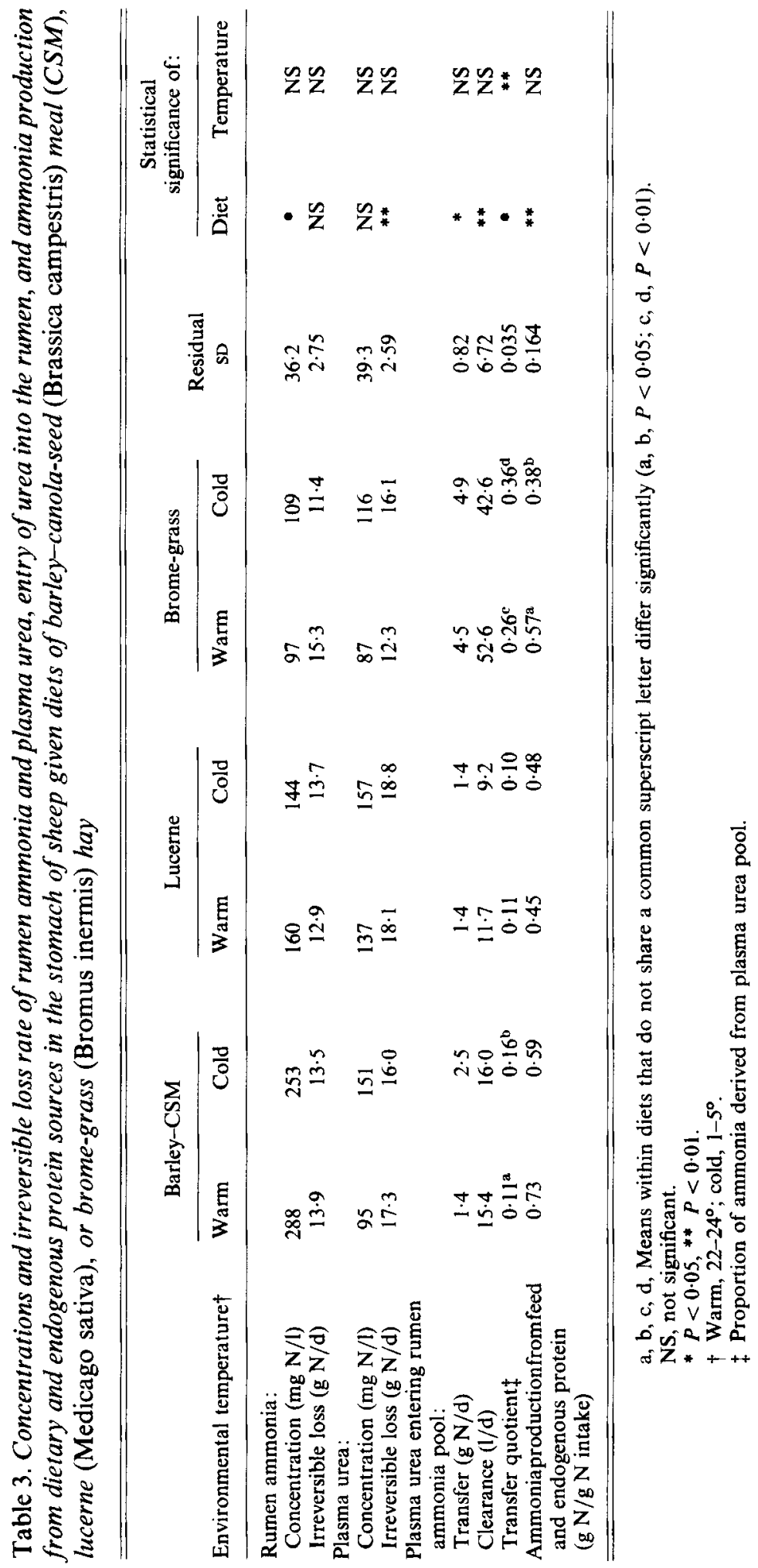




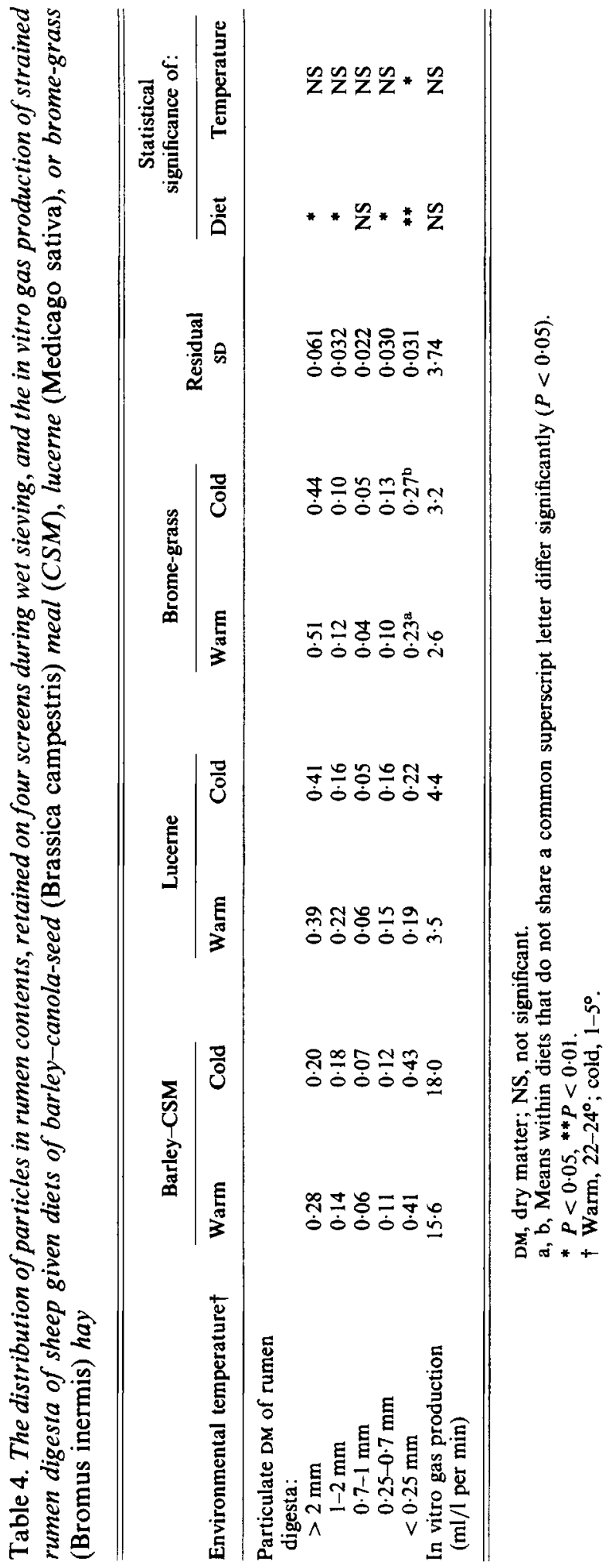




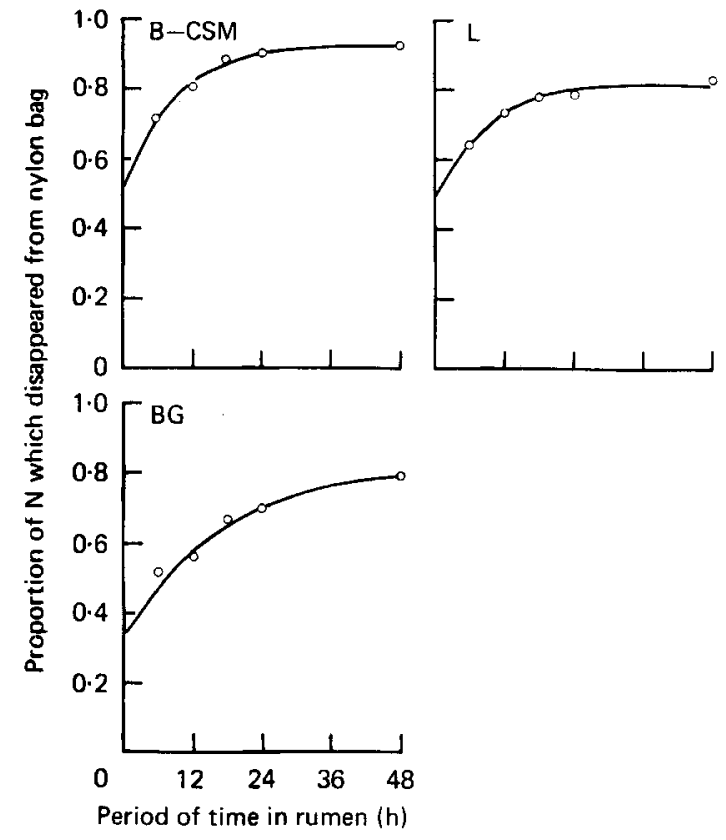

Fig. 2. Disappearance of nitrogen from nylon bags containing barley-canola-seed (Brassica campestris) meal (B-CSM), lucerne (Medicago sativa, L) or brome-grass (Bromus inermis; BG), incubated in the rumen of sheep given the same diets over $48 \mathrm{~h}$ periods. The fitted lines are described by equations presented in Table 5.

particles (Table 4). Also, there was a greater proportion $(0 \cdot 4)$ of very small particles (passing through the $0.25 \mathrm{~mm}$ screen) in the rumen digesta of sheep given barley-CSM than for hay-fed sheep, where the proportion was $0 \cdot 2-0 \cdot 3$.

In vitro gas production was markedly higher in strained rumen fluid from sheep given barley-CSM than for the hay diets (Table 4). No significant differences in gas production were observed between warm and cold-exposed sheep.

\section{Nylon bag experiment}

There was no significant difference between warm- and cold-exposed sheep in the time course of disappearance of $\mathrm{N}$ from nylon bags within each diet. The extent of $\mathrm{N}$ disappearance from the nylon bags with time in the rumen is shown graphically in Fig. 2 and the estimates of the constants are given in Table 5. The potentially-degradable $\mathrm{N}$ (sum of $a, b$ ) was 0.93 , 0.82 and 0.83 of total $\mathrm{N}$ for the barley-CSM, lucerne, and brome-grass diets respectively. Calculations of the proportion of feed $\mathrm{N}$ escaping rumen digestion were made using the outflow rate of ${ }^{103} \mathrm{Ru}-\mathrm{P}$ as the fractional outflow rate of undegraded dietary protein and the results of the nylon bag experiment, by the method of Orskov \& McDonald (1979). The results predicted that feed $\mathrm{N}$ escaping rumen digestion would be ( $\mathrm{g} \mathrm{N} / \mathrm{g} \mathrm{N}$ intake) $0 \cdot 17$ for the barley-CSM diet, 0.44 for the brome-grass diet, and 0.29-0.33 for the lucerne diet. These estimates were smaller than measured values (Table 2) by $1 \cdot 1 \mathrm{~g} \mathrm{~N} / \mathrm{d}$ for the barley-CSM diet and approximately $2.3 \mathrm{~g} \mathrm{~N} / \mathrm{d}$ for the lucerne diet. For sheep given brome-grass hay, the measured values of 0.40 and 0.49 of dietary $\mathrm{N}$ escaping rumen digestion (Table 2) were $0.9 \mathrm{~g} \mathrm{~N} / \mathrm{d}$ less in the warm and $0.9 \mathrm{~g} \mathrm{~N} / \mathrm{d}$ more in the cold than estimated. When the fractional outflow rate of protein $(k)$ was calculated as 1.22 times the turnover rate of ${ }^{103} \mathrm{Ru}-\mathrm{P}$ to allow for retention of ${ }^{103} \mathrm{Ru}-\mathrm{P}$ on large particles which do not 
Table 5. Estimates of the constants $\mathrm{a}, \mathrm{b}$ and $\mathrm{c}$ in the equation $\mathrm{p}=\mathrm{a}+\mathrm{b}\left(1-\mathrm{e}^{-\mathrm{ct}}\right)$ (where $\mathrm{p}$ is the disappearance of protein from the nylon bag $(\%), \mathrm{t}$ is the time $(h)$ in the rumen) fitted to values of disappearance of nitrogen (\%) from diets incubated in nylon bags in the rumen of sheep given the same diets of barley-canola-seed (Brassica campestris) meal (CSM), lucerne (Medicago sativa), or brome-grass (Bromus inermis) hay

(Mean values and standard deviations)

\begin{tabular}{|c|c|c|c|c|c|c|}
\hline & \multicolumn{2}{|c|}{ Barley-CSM } & \multicolumn{2}{|c|}{ Lucerne } & \multicolumn{2}{|c|}{ Brome-grass } \\
\hline & Mean & SD & Mean & SD & Mean & SD \\
\hline$a$ & $49 \cdot 2$ & $5 \cdot 2$ & $48 \cdot 4$ & $5 \cdot 2$ & $32 \cdot 7$ & $4 \cdot 0$ \\
\hline$b$ & $43 \cdot 6$ & $4 \cdot 7$ & $34 \cdot 1$ & $4 \cdot 7$ & $50 \cdot 5$ & $3 \cdot 3$ \\
\hline$c$ & $0 \cdot 110$ & 0.018 & 0.108 & 0.023 & 0.0558 & 0.0111 \\
\hline
\end{tabular}

readily escape from the rumen (R. M. Dixon and L. P. Milligan, unpublished information), the estimates of degradability derived from nylon bags were smaller than for dietary protein digestibility, measured by flow of digesta, by $1.3 \mathrm{~g} \mathrm{~N} / \mathrm{d}$ for the barley-CSM diet and by $2.7 \mathrm{~g} \mathrm{~N} / \mathrm{d}$ for the lucerne diet. For sheep given brome-grass, the estimated values were $1.4 \mathrm{~g} \mathrm{~N} / \mathrm{d}$ less than measured in the warm, and $0.3 \mathrm{~g} \mathrm{~N} / \mathrm{d}$ greater than measured in the cold. For the brome-grass diet, dietary protein digestibility $(D)$ in the stomach derived from flow of NAN into the intestines was related to the proportion $(L)$ of large particles (retained on the 1 and $2 \mathrm{~mm}$ screens) in rumen digesta according to the relationship:

$$
D=1 \cdot 15( \pm 0 \cdot 0052) L-0 \cdot 12(r 0.67)
$$

Addition of ${ }^{103} \mathrm{Ru}-\mathrm{P}$ turnover time as an independent variable in a multiple regression did not significantly increase variance accounted for in the prediction. The relationships between $D$ and $L$ for lucerne and barley-CSM diets were not significant $(P>0.05)$.

\section{DISCUSSION}

\section{Digestion in the gastrointestinal tract}

The results of the present experiment differ in several respects from those obtained when closely-shorn sheep were given brome-grass pellets and exposed to warm (approximately $20^{\circ}$ ) and cold (approximately $0^{\circ}$ ) ambient temperatures (Kennedy et al. 1976; Kennedy \& Milligan, 1978). In experiments with ground and pelleted grass, cold exposure resulted in a significant reduction of turnover time of digesta marker and of OM digestion in the stomach but not in the intestines. In contrast, in the present experiments, no differences in site or quantity of OM digestion due to cold exposure were evident for the barley-CSM diet, but a decline in OM and CWC digestion by $0.05-0.08$ units was observed in sheep given brome-grass and lucerne hay at $1-5^{\circ}$ (Table 1$)$. For both brome-grass and lucerne diets, intestinal OM digestion was depressed by $35-42 \mathrm{~g} / \mathrm{d}$ in cold-exposed sheep; however a reduction in $O M$ digestion in the stomach was observed for only the lucerne diet, despite the tendency for increased in vitro gas production in cold-exposed sheep.

The apparent interaction between diet, method of diet processing, and environmental temperature with the rate and site of OM digestion may have been associated with differing fermentation rates and rate of comminution of large digesta particles within the rumen. The increased gut motility observed during cold exposure of sheep (Westra \& Christopherson, 1976) would be expected to result in decreased OM digestion in the stomach by increasing the rate of passage of particles eligible to escape from the rumen. However, when the rate 
of digestion of $\mathrm{OM}$ in the rumen is high relative to rate of passage of dietary residues, as was the situation for the barley-CSM diet, or the pool size or digestibility of the small particles is reduced by previous digestion as large particles, as was the situation for the brome-grass diet, it is likely that cold-induced changes in stomach OM digestion would not be as marked as for the pelleted brome-grass diet studied previously. Also, differences in the rate of particle size reduction between grasses and legumes (Moseley \& Jones, 1979) and in the proportion and digestion rate of structural carbohydrate would contribute to the different effects of cold exposure on digestion in sheep given chopped brome-grass and lucerne. However, these factors do not provide a ready explanation of the lack of significant change due to cold in sheep given brome-grass hay in the turnover time of the digesta marker, ${ }^{103} \mathrm{Ru}-\mathrm{P}$, which is predominantly associated with small particles (Faichney \& Griffiths, 1978). The interaction between ${ }^{103} \mathrm{Ru}-\mathrm{P}$ turnover time in the intestines and method of preparation of brome-grass with ambient temperature (this experiment; Kennedy \& Milligan, 1978) may be due to an increase in amounts of digesta in the intestines of cold-exposed sheep given pelleted grass, but not for sheep given chopped brome-grass. Physical enlargement of the caecum does occur when ground, pelleted diets are substituted for chopped hay diets (Thomson et al. 1972).

\section{$N$ digestibility and microbial growth}

The proportion of dietary lucerne $\mathrm{N}$ which escaped digestion $(0 \cdot 20-0 \cdot 24)$ was slightly lower in this experiment than in similar experiments using artificially dried lucerne (Mathers \& Miller, 1981) in which the value was $0 \cdot 28$, but was similar to $0 \cdot 20-0 \cdot 21$ calculated in other studies with lucerne (Pilgrim et al. 1970; Lindsay \& Hogan, 1972). Use of coefficients derived from the nylon bag experiment to predict in vivo protein escape from the rumen together with estimates of rate of digesta movement from the rumen using either the measured or corrected value for ${ }^{103} \mathrm{Ru}-\mathrm{P}$ turnover did not provide good absolute estimates for actual protein degradability for lucerne and barley-CSM diets but did provide acceptable relative estimates of the decreased degradation of feed $\mathrm{N}$ due to cold exposure. This lack of agreement was undoubtedly partly due to contamination of dietary residues in the nylon bags by rumen microbes. Mathers \& Aitchison (1981) found that the degradability of lucerne protein was increased from 0.61 to 0.65 when microbial contamination was allowed for. Predicted decreases (using corrected ${ }^{103} \mathrm{Ru}-\mathrm{P}$ turnover) in degradation with cold exposure were 0.033 and $\mathbf{0 . 0 1 4}$ for lucerne and barley-CSM, compared to actual decreases of 0.047 and 0.013 respectively.

The ability closely to predict in vivo degradation from nylon bag information may be limited by differences in lag times of microbial colonization of the ground feed in nylon bags and of feed subjected to normal mastication and ensalivation as well as by differences in rate of fermentation. Poppi et al. (1981) found masticated grass was digested in nylon bags at 1.35 times the rate of chopped grass, and that both values substantially underestimated rates of digestion calculated from in vivo values of turnover time and rumen digestion. However, the prediction of protein degradability also depends on the accuracy of use of ${ }^{103} \mathrm{Ru}-\mathrm{P}$ as an indicator of digesta turnover. Because the ${ }^{103} \mathrm{Ru}-\mathrm{P}$ associates with both large and small digesta particles and migrates rapidly between the two pools (Faichney \& Griffiths, 1978 ; R. M. Dixon, personal communication), the turnover time of ${ }^{103} \mathrm{Ru}-\mathrm{P}$ will underestimate that of small particles to the extent of the proportion of ${ }^{103} \mathrm{Ru}-\mathrm{P}$ adsorbed onto large particles. The disparity between estimated (using the corrected value for ${ }^{103} \mathrm{Ru}-\mathrm{P}$ turnover) and measured protein degradation does not take into account the digestion of protein from large particles in the rumen. Evidence of the importance of the large-particle pool can be deduced from the correlation between proportion of large particles in brome-grass digesta and protein degradability. This observation indicates that for chopped brome-grass, unlike 
the situation for ground and pelleted grass, effectiveness of rumination may have been increased in cold-exposed sheep in the absence of changes in the small particle turnover rate, with a resultant reduction in the proportion of large particles in rumen digesta and of digesta true turnover time. More rapid breakdown of large particles apparently resulted in relatively greater escape of dietary protein from digestion than for DM, in agreement with observations from the nylon bag experiment that the rate of $\mathrm{N}$ fermentation was greater than that of CWC fermentation (Kennedy et al. unpublished results). In this regard, the observations of Gonyou et al. (1979) that rumination activity in steers was inversely related to ambient temperature, are pertinent.

For sheep given brome-grass pellets in earlier studies, efficiency of microbial synthesis was high (40-54 g N/kg OM apparently fermented) and positively related to the fractional turnover rates of liquid and particle markers (Kennedy et al. 1976; Kennedy \& Milligan, 1978). However, in the present experiments, there was little relationship between efficiency of synthesis and ${ }^{103} \mathrm{Ru}-\mathrm{P}$ turnover time within diets. A similar result was reported by Mathers \& Miller (1981) for sheep given a range of concentrate-forage diets. It is likely that digesta marker turnover in the rumen of sheep given a ground, pelleted diet, as contrasted to chopped hay, more closely represents turnover of both dietary residues and microbial material, and therefore may approximate the specific growth rate of micro-organisms (Stouthamer \& Bettenhaussen, 1973). In the more heterogenous digesta in sheep given a chopped diet, a significant proportion of microbes would be attached to large particles of digesta. Their turnover may not be adequately predicted from the turnover time of ${ }^{103} \mathrm{Ru}-\mathrm{P}$.

\section{Sources of ammonia in the rumen}

Cold exposure significantly affected $\mathrm{N}$ dynamics only in sheep given chopped brome-grass (Table 3). Notably, the rate of ammonia production from feed and endogenous protein sources when that diet was given was reduced with cold exposure from 0.57 to $0.38 \mathrm{~g} \mathrm{~N} / \mathrm{g} \mathrm{N}$ intake, which was an amount $(4.1 \mathrm{~g} \mathrm{~N} / \mathrm{d})$ twice the increase $(2.0 \mathrm{~g} \mathrm{~N} / \mathrm{d})$ in feed protein which escaped digestion in the stomach. Similar calculations from results previously presented (Kennedy \& Milligan, 1978) show that cold exposure of closely-shorn sheep given brome-grass pellets resulted in a reduction of rumen ammonia production from 0.54 to $0.43 \mathrm{~g} \mathrm{~N} / \mathrm{g} \mathrm{N}$ intake, an amount less than the increased escape $(3.0 v .5 .0 \mathrm{~g} \mathrm{~N} / \mathrm{d})$ of dietary protein from the stomach. Assuming that $6.5 \mathrm{~g} \mathrm{~N} / \mathrm{d}$ of endogenous protein enters the rumen (Kennedy \& Milligan, $1980 b)$ it was calculated that the production of ammonia $(A ; \mathrm{g} \mathrm{N} / \mathrm{d})$ from protein sources in the rumen was related to the amount of protein from feed and endogenous sources fermented in the stomach $(P F, \mathrm{gN} / \mathrm{d})$ in sheep given chopped brome-grass by:

$$
A=0.935( \pm 0.0280) P F-7 \cdot 0(r 0.81)
$$

This relationship implies that practically all the protein $\mathrm{N}$ fermented in excess of $7.0 \mathrm{~g} / \mathrm{d}$ (equivalent to $0 \cdot 32$ of dietary $\mathrm{N}$ intake) passes through the ammonia pool. This relationship over-predicts ammonia production by $6-8 \mathrm{~g} \mathrm{~N} / \mathrm{d}$ for the barley and lucerne diets, which have a smaller proportion of slowly fermentable $\mathrm{N}(b$; Table 5$)$. It is uncertain whether the protein fraction that is largely degraded to ammonia can be identified as the slowly fermented fraction estimated from the nylon bag experiment, but it may be significant that cellulolytic bacteria have a requirement for ammonia-N (Bryant \& Robinson, 1963) rather than amino acids.

Transfer of endogenous plasma urea to the rumen constituted only a minor proportion of rumen ammonia flux for barley-CSM and lucerne diets, but its contribution $(4.5-4.9 \mathrm{~g} \mathrm{~N} / \mathrm{d})$ was more significant for sheep given brome-grass. Clearance of plasma urea into the rumen of sheep given chopped brome-grass was similar to that observed for ground, 
pelleted brome-grass (Kennedy et al. 1981), and was related to rumen ammonia concentration in a manner like that previously described (Fig. 1; Kennedy \& Milligan, 1980a). Clearance of endogenous urea was relatively high (approximately $16 \mathrm{l} / \mathrm{d}$ ) for sheep given barley-CSM considering ammonia concentrations were also high, but this observation is in agreement with the positive relationship observed in other experiments (e.g. Kennedy et al. 1981) between quantity of readily-fermentable $\mathrm{OM}$ in the diet and clearance.

Several important conclusions may be drawn from the present study. First, the effect of ambient temperature on digestion apparently depends on changes of rumen digesta turnover rates and the nature of the diet. Thus, digestion in sheep given diets (e.g. concentrates) characterized by rapid digestion and slow turnover of rumen digesta is less likely to be affected by variations in turnover time of digesta caused by cold exposure than in sheep given more slowly digestible diets (e.g. grass hay) which are retained for less time in the rumen. Secondly, the limited success of attempts to relate digestion of dietary material in nylon bags to observed in vivo digestion may have been at least partly related to the use of ${ }^{103} \mathrm{Ru}-\mathrm{P}$ as a marker for small particles, and partly to contamination of dietary residues in nylon bags by microbes. In addition, the observations for sheep given chopped brome-grass that there was a relationship between ${ }^{103} \mathrm{Ru}-\mathrm{P}$ turnover time and fermentation in the stomach of OM, but not of dietary protein, together with the relationship between feed protein fermentation and proportion of large particles in rumen digesta, suggest that absolute description of digestion of dietary components of differing rates of fermentability from nylon bag experiments may be difficult for forage diets, although relative values may be obtained. Finally, the suggestion from ${ }^{15} \mathrm{~N}$ information that the amount of dietary protein fermented may be closely related to the extent to which degradation to ammonia occurs, deserves clarification.

Technical assistance was provided by Messrs N. Trueblood and W. Whitmore. Dr R. T. Hardin and Mr R. Weingardt advised and carried out statistical analyses. Dr W. McGill provided ${ }^{15} \mathrm{~N}$ analyses. Financial assistance was provided by the Agricultural Research Council of Alberta and the Natural Sciences and Engineering Research Council of Canada.

\section{REFEREN CES}

Bryant, A. M. \& Robinson, I. M. (1963). J. Dairy Sci. 46, 150.

Faichney, G. J. (1975a). Aust. J. agric. Res. 26, 219.

Faichney, G. J. (1975b). In Digestion and Metabolism in Ruminants [1. W. McDonald \& A. C. I. Warner, editors]. Armidale, Australia: University of New England Publishing Unit.

Faichney, G. J. \& Griffiths, D. A. (1978). Br. J. Nutr. 40, 71.

Gonyou, H. W., Christopherson, R. J. \& Young, B. A. (1979). Appl. Anim. Ethol. 5, 113.

Harrop, C. J. F. (1974). J. agric. Sci., Camb. 83, 249.

Kennedy, P. M., Christopherson, R. J. \& Milligan, L. P. (1976). Br. J. Nutr. 36, 231.

Kennedy, P. M., Clarke, R. T. J. \& Milligan, L. P. (1981). Br. J. Nutr. 46, 533.

Kennedy, P. M. \& Milligan, L. P. (1978). Br. J. Nutr. 39, 105.

Kennedy, P. M. \& Milligan, L. P. (1980a). Can. J. Anim. Sci. 60, 205.

Kennedy, P. M. \& Milligan, L. P. (1980b). Can. J. Anim. Sci. 60, 1029.

Lindsay, J. R. \& Hogan, J. P. (1972). Aust. J. agric. Res. 23, 321.

Marsh, W. H., Fingerhut, B. \& Kirsch, E. (1957). Am. J. clin. Path. 28, 681.

Mathers, J. C. \& Aitchison, E. M. (1981). J. agric. Sci., Camb. 96, 691.

Mathers, J. C. \& Miller, E. L. (1981). Br. J. Nutr. 45, 587.

Moseley, G. \& Jones, J. R. (1979). Br. J. Nutr. 42, 139.

Mudgal, V. D., Dixon, R. M., Kennedy, P. M. \& Milligan, L. P. (1982). J. Anim. Sci. (In the Press).

National Academy of Sciences (1975). Nutrient Requirements of Sheep. Washington, DC: National Academy of Sciences.

Nolan, J. V. \& Leng, R. A. (1972). Br. J. Nutr. 27, 177.

Ørskov, E. R. \& McDonald, I. (1979). J. agric. Sci., Camb. 92, 499.

Phillipson, A. T. (1964). In Mammalian Protein Metabolism vol. 1, p. 71 [H. N. Munro \& J. B. Allison, editors]. London: Academic Press.

Pilgrim, A. F., Gray, F. V., Weller, R. A. \& Belling, C. B. (1970). Br. J. Nutr. 24, 589. 
Poppi, D. P., Minson, D. J. \& Ternouth, J. M. (1981). Aust. J. agric. Res. 32, 109.

Shipley, R. A. \& Clark, R. E. (1972). Tracer Methods for in vivo Kinetics. New York and London: Academic Press. Stouthamer, A. H. \& Bettenhaussen, C. W. (1973). Biochim. biophys. Acta 301, 53.

Tan, T. N., Weston, R. H. \& Hogan, J. P. (1971). Int. J. appl. Radiat. Isotopes 22, 301.

Thomson, D. J., Beever, D. E., Coelho da Silva, J. F. \& Armstrong, D. G. (1972). Br. J. Nutr. $28,31$.

Uden, P., Colucci, P. E. \& Van Soest, P. J. (1980). J. Sci. Fd Agric. 31, 625.

Westra, R. \& Christopherson, R. J. (1976). Can. J. Anim. Sci. 56, 699.

Young, B. A. \& Degen, A. A. (1981). In Environmental Aspects of Housing for Animal Production [J. A. Clark, editor]. London: Butterworths.

Young, B. A., Kerrigan, B. \& Christopherson, R. J. (1975). Can. J. Anim. Sci. 55, 17. 